\title{
Chromosomal Q-heterochromatin Regions in Alcoholics and Drug Addicts
} Ibraimov $\mathbf{A l}^{*}$

Institute of Balneology and Physiotherapy, Bishkek and Laboratory of Human Genetics, National Center of Cardiology and Internal Medicine, Bishkek, Kyrgyzstan *Corresponding author: Ibraimov Al, Institute of Balneology and Physiotherapy, Bishkek and Laboratory of Human Genetics, National Center of Cardiology and Internal Medicine, Bishkek, Kyrgyzstan, Tel: +996 07003056 20; E-mail: ibraimov_abyt@mail.ru

Received date: December 20, 2015; Accepted date: September 28, 2016; Published date: October 05, 2016

Copyright: () 2016 Ibraimov Al. This is an open-access article distributed under the terms of the Creative Commons Attribution License, which permits unrestricted use, distribution and reproduction in any medium, provided the original author and source are credited.

\begin{abstract}
We studied quantitative variability of chromosomal Q-heterochromatin regions (Q-HRs) in alcoholics and drug addicts in various racial and ethnic groups. It was found that in the genome of alcoholics the amount of chromosomal Q-HRs is significantly lower than in control samples and drug addicts, whereas the latter have the greatest number of chromosomal Q-HRs.
\end{abstract}

Keywords: Chromosomal Q-heterochromatin; Alcoholism; Drug addiction

\section{Introduction}

Despite the fact that human chromosomal Q-heterochromatin regions (Q-HRs) have been studied for 45 years, their biological role and nature remain unclear. The existence of Q-HRs variability in twelve Q-polymorphic loci of seven autosomes and the distal portion of the long arm of chromosome $\mathrm{Y}$ in populations is a well-established fact [1]. A remarkable feature of human chromosomal Qheterochromatin regions is that individuals in a population differ in the number, location, size and intensity of fluorescence of these specific fluorescent areas [2-12].

Results of our extensive comparative population studies show that modern human populations differ considerably from each other. These differences are undoubtedly related to environmental factors rather than to racial or ethnic features. Specifically, the mean number of QHRs is considerably lower in the genome of populations living permanently in northern latitudes and high-altitude regions as compared to permanent residents of temperate zones of Eurasia and low-attitude regions of subequatorial Africa [9,13-21].

The problem of alcohol abuse is exclusively human. Produced and consumed since at least the sixth century, surrounded by wonder and regulation, alcoholic beverages have played a central role in all cultures to-date. There are large individual differences in the rate of ethanol metabolism, and a single dose may have widely different effects within a population. Indeed, there has been very strong evidence that ethanol metabolism varies among racial groups [22]. According to data of certain authors, there is a tendency towards an increase in the consumption of strong alcoholic beverages from southern regions to northern ones [23-25]. An analogous trend was traced within one state and even territorial region [26].

Taking into account the well-known role of alcohol and drugs in metabolism, we have carried out a pilot study in order to detect possible relations between the tendency of individuals to consume strong alcoholic beverages, as well as drugs, and the amount of chromosomal Q-HRs in their genome taking into account their racial and ethnic features.

\section{Materials and Methods}

Using identical methods, we were the first to examine patients undergoing treatment in a narcological dispensary (in Bishkek, Kyrgyzstan) in connection with alcoholic and narcological intoxication. It is difficult to unequivocally label them as sick people, for, as we have ascertained, at present, at least under conditions of the medical service functioning in our country, various interpretations of "alcoholism" and "drug addiction" do not allow us to adopt a unified system of their classification and diagnosis. Since our sample included subjects receiving medical care of their own free will or at the urgent request of their relatives, we cannot call them sick in the strictly clinical sense of the word. Therefore, we conditionally call them alcoholics and drug addicts.

In order to study chromosomal Q-HRs variability in alcoholics we selected those of both sexes belonging to two ethnic groups (Kyrgyz and Russians). However, the group of drug addicts included all those who received medical care regardless of their racial and ethnic affiliation, since narcomania appeared in our country as a medico social phenomenon just recently. But owing to a number of social and psychological factors women with narcomania either conceal it or do not seek medical care. That is why our sample included male drug addicts. The age of the subjects studied ranged from 18 to 60 years.

Chromosomal preparations were made using short-term cultures of peripheral blood lymphocytes. The cultures were processed according to slightly modified [27] conventional methods [28]. The dye used was propylquinacrine mustard. Calculation and registration of chromosomal Q-HRs variability was performed using the criteria and methods described in detail elsewhere [16,18].

To describe Q-HRs variability in our samples we used three main quantitative characteristics of this cytogenetic phenomenon: (1) the distribution of Q-HRs in the populations studied, i.e., the distribution of individuals having different numbers of Q-HRs in the karyotype regardless of the location (distribution of Q-HRs), which also reflected the range of Q-HRs variability in the population genome; (2) the derivative of this distribution, an important population characteristic, i.e. the mean number of Q-HRs per individual; (3) the frequency of QHRs in seven Q-polymorphic autosomes in the population. 
Citation: Ibraimov Al (2016) Chromosomal Q-heterochromatin Regions in Alcoholics and Drug Addicts. Biol Med (Aligarh) 8: 346. doi:

Page 2 of 5

The $\chi^{2}$ test was used to compare distributions of Q-HRs. The mean numbers of Q-HRs per individual were compared using the Student $\mathrm{t}$ test.

\section{Results}

Table 1 shows the distribution of the numbers and mean number of Q-HRs on autosomes in alcoholics and drug addicts, as well as in the control groups (residents of Bishkek). To begin with, let us note that the appropriate statistical analysis showed that alcoholics representing two different ethnic groups did not differ significantly in all the quantitative characteristics of chromosomal Q-HRs variability, and this admitted to pool them into one group. As it follows from the Table 1, alcoholics are characterized by the lowest value of the mean number of Q-HRs per individual in the population $(\overline{\mathrm{x}})$ and by the narrowest range of variability of the number of chromosomal Q-HRs among all the samples studied. Although subjects with drug abuse typically had the highest $\bar{x}$ value, nevertheless it should be noted that the range of variability of the number of Q-HRs was as narrow in the as that in alcoholics.

\begin{tabular}{|c|c|c|c|c|c|}
\hline \multirow{3}{*}{ Number of Q-HRs } & \multicolumn{2}{|c|}{ Alcoholics } & \multirow{2}{*}{$\begin{array}{c}\text { Drug addicts } \\
\qquad(n=100)\end{array}$} & \multicolumn{2}{|c|}{ Controls } \\
\hline & Kyrgyz $(n=48)$ & Russians ( $n=57$ ) & & Kyrgyz (n=202) & Russians ( $n=556$ ) \\
\hline & 1 & II & III & IV & $\mathbf{v}$ \\
\hline 0 & $7(14.5)$ & $10(17.5)$ & & $18(8.9)$ & $46(8.3)$ \\
\hline 1 & $23(47.9)$ & $17(29.8)$ & & $37(18.3)$ & $119(21.4)$ \\
\hline 2 & $12(25.0)$ & $22(38.5)$ & $12(12.0)$ & $72(35.6)$ & 194 (34.9) \\
\hline 3 & $6(12.5)$ & $6(10.5)$ & $13(13.0)$ & $35(17.3)$ & $122(21.9)$ \\
\hline 4 & & $2(3.5)$ & $36(36.0)$ & $29(14.4)$ & $57(10.2)$ \\
\hline 5 & & & $30(30.0)$ & $9(4.5)$ & $16(2.9)$ \\
\hline 6 & & & $9(9.0)$ & $2(1.0)$ & $2(0.4)$ \\
\hline \multirow[t]{7}{*}{ Total number of Q-HRs } & 65 & 87 & 411 & 459 & 1193 \\
\hline & $X^{2}{ }_{1}, I I=2.40$ & $X^{2}{ }_{1}, I I=78.39$ & $X^{2}{ }_{I}, I V=21.50$ & $x^{2} I, v=21,78$ & $X^{2}{ }^{11, \| I I}=57.21$ \\
\hline & $d f=1$ & $d f=1$ & $d f=1$ & $d f=1$ & $d f=1$ \\
\hline & $P>0.50$ & $P<0.001$ & $\mathrm{P}<0.01$ & $\mathrm{P}<0.01$ & $P<0.001$ \\
\hline & $X^{2} I I, I V=8.34$ & $\mathrm{X}^{2} \mathrm{II}, \mathrm{v}=7.52$ & $X^{2}{ }^{I I I,}, I V=33.29$ & $X^{2} I I I, v=39.65$ & $\mathrm{X}^{2} \mathrm{IV}, \mathrm{v}=0.43$ \\
\hline & $d f=1$ & $d f=1$ & $d f=1$ & $d f=1$ & $d f=1$ \\
\hline & $P<0.05$ & $P<0.001$ & $P<0.001$ & $P<0.001$ & $P>0.05$ \\
\hline \multirow[t]{7}{*}{ Mean number of Q-HRs } & $1.35 \pm 0.128$ & $1.53 \pm 0.135$ & $4.11 \pm 0.113$ & $2.27 \pm 0.094$ & $2.15 \pm 0.51$ \\
\hline & $t_{1, I I}=0,96$ & $\mathrm{t}_{\mathrm{l}, \mathrm{III}}=16.17$ & $t_{1, I V}=5.79$ & $\mathrm{t}_{\mathrm{l}, \mathrm{V}}=5.81$ & $t_{I I, ~ I I I}=4.66$ \\
\hline & $d f=103$ & $d f=118$ & $d f=106$ & $\mathrm{df}=64$ & $d f=112$ \\
\hline & $P>0.300$ & $P<0.000$ & $P<0.000$ & $P<0.000$ & $P<0.000$ \\
\hline & $\mathrm{t}_{\mathrm{II}, \mathrm{IV}}=4.50$ & $\mathrm{t}_{\mathrm{II}, \mathrm{v}}=3.76$ & $\mathrm{t}_{\mathrm{III}, \mathrm{IV}}=12.52$ & $\mathrm{t}_{\mathrm{III}, \mathrm{v}}=15.81$ & $\mathrm{t}_{\mathrm{IV}, \mathrm{v}}=1.12$ \\
\hline & $d f=118$ & $\mathrm{df}=611$ & $d f=232$ & $d f=143$ & $d f=328$ \\
\hline & $P<0.000$ & $P<0.000$ & $P<0.000$ & $P<0.000$ & $P>0.200$ \\
\hline
\end{tabular}

Table 1: Distribution and mean number of Q-HRs per individual in alcoholics, drug addicts and controls.

Table 2 presents data regarding the comparative analysis of alcoholics with subjects suffering from narcomania. As noted above, we were unable to divide our sample of drug addicts according to their ethnic affiliation because it was too small to carry out an adequate statistical analysis, and therefore, we just indicated their number. Nevertheless, in determining the value of the mean number of Q-HRs $(\mathrm{x})$ in all the ethnic samples of drug addicts we invariably found $\bar{x}$ to amount to four (these data are not presented here). In any case, according to our data the content of chromosomal Q-HRs in the genome of drug addicts proved to be considerably greater in drug addicts than in the controls and especially in alcoholics.

Table 3 shows the frequency of the Q-HRs in seven Q-polymorphic autosomes in the samples studied. As can be seen from this Table, another quantitative relationship exists between Q-HRs frequencies on 
seven autosomes, namely they tend to be lower in all the autosomes, depending on the $\overline{\mathrm{x}}$ value, with the exception of autosomes 4 containing the lowest amount of Q-HRs in the human population genome and vice versa. Of interest is the fact that this difference was most pronounced in autosomes 3 and 13 containing more than half of the Q-HRs of the human population genome. At the same time, all the samples studied did not differ significantly from each other in the portion of Q-HRs in the polymorphic loci of seven Q-polymorphic autosomes, in keeping with our previous observations [16-19,21,29].

\begin{tabular}{|c|c|c|c|}
\hline \multirow{2}{*}{ Number of Q-HRs } & Alcoholics & Drug addicts & \multirow{2}{*}{$\begin{array}{c}\text { Ethnic } \\
\text { composition of } \\
\text { drug addicts }\end{array}$} \\
\hline & $(n=105)$ & $(n=100)$ & \\
\hline & 1 & $\|$ & \\
\hline 0 & $17(16.2)$ & & 1. Kyrgyz-34 \\
\hline 1 & $40(38.1)$ & & 2. Russians- 32 \\
\hline 2 & $34(32.4)$ & $12(12.0)$ & 3. Uighurs-14 \\
\hline 3 & $12(11.4)$ & $13(13.0)$ & 4. Koreans-18 \\
\hline 4 & $2(1.9)$ & $36(36.0)$ & 5.Germans-2 \\
\hline 5 & & $30(30.0)$ & \\
\hline 6 & & $9(9.0)$ & \\
\hline \multirow[t]{4}{*}{ Total number of Q-HRs } & 152 & 411 & \\
\hline & \multicolumn{3}{|l|}{$X 21, I I=114.23$} \\
\hline & \multicolumn{2}{|l|}{$d f=1$} & \\
\hline & \multicolumn{2}{|l|}{$P<0.001$} & \\
\hline \multirow[t]{4}{*}{ Mean number of Q-HRs } & $1.45 \pm 0.094$ & $4.1 \pm 0.113$ & \\
\hline & \multicolumn{3}{|l|}{$\mathrm{tl}, \mathrm{Il}=18.17$} \\
\hline & \multicolumn{2}{|l|}{$d f=203$} & \\
\hline & \multicolumn{2}{|l|}{$P<0.000$} & \\
\hline
\end{tabular}

Table 2: Distribution and mean number of Q-HRs per individual in alcoholics and drug addicts.

\section{Discussion}

It is found that non-genic part of human genome makes about $98 \%$ of cell nucleus DNA. Approximately 15-20\% of this non-coding part of human DNA is constitutive heterochromatin. There are two types of constitutive heterochromatin: C- and Q-heterochromatin. Cheterochromatin regions (C-HRs) are found in the genome of all higher eukaryotes, while Q-heterochromatin regions (Q-HRs) are only in the genome of three higher primates (Homo sapiens, Pan troglodytes and Gorilla gorilla). Human chromosomes possess both types of constitutive heterochromatin. However, there is a fundamental difference between them: quantitative variability of chromosomal QHRs in the genome exists only in human populations. In man Cheterochromatin is present in all his chromosomes, varying mainly in size, while Q-heterochromatin can only be detected on seven autosomes and the Y-chromosome. In this case individuals in a population differ from each other on the number of chromosomal QHRs.
However, the question of possible biological role of chromosomal heterochromatin regions in human life remains open. Since human chromosomal C- and Q-HRs have no structural genes, the traditional "genotype $\rightarrow$ phenotype" approach is unacceptable in this case. To search a way out of the situation, we came back to the hypothesis of cell thermoregulation (CT) $[30,31]$. CT is the process of equalization of temperature difference between cytoplasm and nucleus and finally inside of the whole cell. Structural basis of CT is peripheral layer of condensed chromatin (CC) which is chromosomal C- and Q-HRs. We assume that thermal energy transfer between the cytoplasm and the nucleus is carried out through this dense layer of peripheral CC, located inside of the nuclear envelope.

Certainly, CT hypothesis should be checked in vivo on the cell level. But we have not had such opportunity till present. Nevertheless, we have checked this hypothesis on the level of human organism assuming that CT is the basis for heat conductivity of whole cell part of body. These researches showed that individuals in population truly differ from each other in body heat conductivity (BHC) and its level depends on the amount of chromosomal Q-HRs in human genome. In other words, there are some parallels in the distribution of the amount of chromosomal Q-HRs and variability of BHC at the level of human populations [32].

In the available literature we were unable to find biological or genetic markers confirmed by independent studies, indicating predisposition to alcoholism or drug addiction in man. But there are facts that were repeatedly confirmed, at least on the territory of the exUSSR: 1) there is gradient of consumption of strong alcoholic beverages from the south to the north in the scale of a country, individual republics, territories and regions 2) strong alcoholic beverages are significantly more frequently consumed by residents of northern latitudes and high-altitude regions, regardless of their nationality, ethnic or religious affiliation [33]. As far as we know, an almost similar picture is observed in countries of Europe and North America [34,35].

Taking into account the above mentioned data we believe that there may be certain relationship between the amount of Q-HRs in the genome, development of alcoholism and drug addiction, especially its relation to the level of human BHC.

The point is that: a) quantitative chromosomal Q-HRs variability only exists in human populations, though this type of heterochromatin is present in the genome of chimpanzee (Pan troglodytes) and gorilla (Gorilla gorilla); b) the problem of alcohol abuse and drug addicts is exclusively human; c) notorious propensity to addiction of southerners to drug addicts and northerners and mountaineers to alcoholism still needs further research.

Actually, life and climate in the Far North or at high altitude predisposes, in a certain sense, to drink alcoholic beverages just in order to get a feeling of thermal comfort. But, as we suppose, one and same dose of alcohol in people with different amounts of chromosomal Q-HRs in their genome can lead to different consequences. Thus, people with low BHC, among other factors, to get a sense of thermal comfort are forced to take a relatively large amount of alcohol, and it eventually leads to more severe intoxication with hangover syndrome, than in individuals with normal or great number of chromosomal QHRs. In other words, for warming of the body of individuals with low $\mathrm{BHC}$ requires more alcohol and time than ones with normal or high $\mathrm{BHC}$, even if they have similar physical characteristics. 
Drug addicts, i.e., individuals with a high BHC also become accustomed to use drugs because of their wish to get a feeling of thermal comfort, but in this case this "pleasure" is actually due to "narcotic cooling", with consequent emotional or other feelings in drug addicts. Perhaps drug addicts intuitively feel that more pleasure can be received by "cooling" of their body through the drugs than "heating" them with alcohol, since their body having high thermal conductivity liable to rapid heating and cooling.

From the data obtained by us, of interest are the following results: 1) alcoholics have the lowest number of Q-HRs in their genome, and they do not differ from each other in all the quantitative characteristics of chromosomal Q-HRs variability despite their different ethnic affiliation (Table 1);2) in the genome of drug addicts the number of QHRs is significantly greater than in controls, especially in subjects abusing in strong alcoholic beverages (Tables 1 and 2); 3) however, all the samples studied do not differ in the relative content (portion) of QHRs in seven Q-polymorphic autosomes, i.e., in no group there was preferential Q-HR localization on seven potentially Q-polymorphic chromosomes (Table 3), and this is again suggesting that Qheterochromatin is not locus-specific material in the genome [17-19,36].

\begin{tabular}{|c|c|c|c|c|}
\hline \multirow[b]{2}{*}{$\begin{array}{l}\text { Location of Q- } \\
\text { HRs }\end{array}$} & \multirow{2}{*}{$\begin{array}{c}\text { Drug addicts } \\
\qquad(n=100)\end{array}$} & \multicolumn{2}{|c|}{ Controls } & \multirow{2}{*}{$\begin{array}{c}\text { Alcoholics } \\
(n=105)\end{array}$} \\
\hline & & $\begin{array}{l}\text { Kyrgyz } \\
(n=202)\end{array}$ & $\begin{array}{c}\text { Russians } \\
(n=556)\end{array}$ & \\
\hline & 1 & II & III & IV \\
\hline \multirow{2}{*}{3} & $134(0.670)^{*}$ & $141(0.349)^{\star}$ & $445(0.400)^{\star}$ & $64(0.305)^{\star}$ \\
\hline & $(32.6)^{\star *}$ & $(30.7)^{\star *}$ & $(37.3)^{* *}$ & $(45.1)^{\star *}$ \\
\hline \multirow{2}{*}{4} & $10(0.050)^{\star}$ & $27(0.067)^{\star}$ & $14(0.013)^{\star}$ & $2(0.010)^{\star}$ \\
\hline & $(2.6)^{\star \star}$ & $(5.9)^{\star \star}$ & $(1.17)^{\star *}$ & $(1.4)^{\star \star}$ \\
\hline \multirow{2}{*}{13} & $145(0.725)^{*}$ & $160(0.396)^{*}$ & $399(0.359)^{*}$ & $42(0.200)^{*}$ \\
\hline & $(35.3)^{* *}$ & $(34.9)^{\star *}$ & $(33.5)^{\star *}$ & $(29.6)^{\star *}$ \\
\hline \multirow{2}{*}{14} & $23(0.005)$ * & $26(0.064)^{*}$ & $76(0.068)^{*}$ & $11(0.052)^{*}$ \\
\hline & $(5.6)^{\star \star}$ & $(5.7)^{\star \star}$ & $(6.4)^{\star \star}$ & $(7.7)^{\star *}$ \\
\hline \multirow{2}{*}{15} & $34(0.170)^{*}$ & $34(0.084)^{*}$ & $94(0.084)^{*}$ & $5(0.024)^{*}$ \\
\hline & $(8.3)^{* *}$ & $(7.4)^{\star *}$ & $(7.9)^{\star *}$ & $(3.5)^{\star *}$ \\
\hline \multirow{2}{*}{21} & $40(0.200)^{*}$ & $43(0.106)^{*}$ & $97(0.087)^{*}$ & $14(0.067)^{*}$ \\
\hline & $(9.7)^{\star \star}$ & $(9.4)^{\star *}$ & $(8.1)^{\star *}$ & $(9.9)^{\star *}$ \\
\hline \multirow{2}{*}{22} & $25(0.125)^{*}$ & $28(0.069)^{*}$ & $68(0.061)^{*}$ & $4(0.019)^{*}$ \\
\hline & $(6.1)^{\star \star}$ & $(6.1)^{\star \star}$ & $(5.7)^{\star *}$ & $(2.8)^{\star \star}$ \\
\hline $\begin{array}{l}\text { Total number of } \\
\text { Q-HRs }\end{array}$ & 411 & 459 & 1193 & 152 \\
\hline $\begin{array}{l}\text { Mean number of } \\
\text { Q-HRs }\end{array}$ & $4.1 \pm 0.113$ & $2.27 \pm 0.094$ & $2.15 \pm 0.510$ & $1.45 \pm 0.094$ \\
\hline
\end{tabular}

*-Q-HR frequency from the number of chromosomes analyzed;

**-Q-HR frequency as percentage of the overall number of chromosomal Q-HR.

Table 3: Q-HRs frequencies in seven Q-polymorphic autosomes in alcoholics, drug addicts and controls.
Here we just draw attention to the fact that in the vulnerability of man to alcoholism and drug addiction is also of significance, in addition to other things, the amount of chromosomal Q-HRs in his genome. We believe that in such a complicated problem as alcoholism and drug addiction in the contemporary world theoretical constructions are not very important. Even when there are the slightest suspicions as to certain biological factors, if they really point to possible predisposition to alcohol and drug abuse, deserve verification by independent investigations, no matter by whom and where such investigations were carried out.

\section{References}

1. Paris Conference (1971) and Supplement 1975. Standartization in human cytogenetics. Birth Defects: Original Article Series, XI. The National Foundation, New York.

2. Geraedts JPM, Pearson PL (1974) Fluorescent chromosome polymorphisms: frequencies and segregation in a Dutch population. Clinical Genetics 6: 247-257.

3. McKenzie WH, Lubs HA (1975) Human Q and C chromosomal variations: distribution and incidence. Cytogenetics and Cell Genetics 14: 97-115.

4. Buckton KE, O’Riordan ML, Jacobs PA, Robinson JA, Hill R, et al. (1976) C- and Q-band polymorphisms in the chromosomes of three human populations. Ann Hum Genet 40: 90-112.

5. Muller HJ, Klinger HP, Glasser M (1975) Chromosome polymorphism in a human newborn population. II. Potentials of polymorphic chromosome variants for characterizing the idiogram of an individual. Cytogenetics and Cell Genetics 15: 239-255.

6. Lubs HA, Patil SR, Kimberling WJ, Brown J, Cohen M, et al. (1977) Qand C-banding polymorphisms in 7 and 8-year-old children: racial differences and clinical significances. In: Hook EB, Porter IH (eds.) Population cytogenetics. Academic Press, London, pp. 133-159.

7. Yamada K, Hasegawa T (1978) Types and frequencies of Q-variant chromosomes in a Japanese population. Human Genetics 44: 89-9.

8. Al-Nassar KE, Palmer CG, Connealy PM, Pao-Lo Yu (1981) The genetic structure of the Kuwaiti population. II. The distribution of Q-band chromosomal heteromorphisms. Hum Genet 57: 423-427.

9. Ibraimov AI, Mirrakhimov MM (1985) Q-band polymorphism in the autosomes and the Y chromosome in human populations. In: Sandberg AA, Alan R (eds.) Progress and Topics in Cytogenetics. The Y chromosome. Part A. Basic Characteristics of the Y chromosome. Liss Inc, New York, pp 213-87.

10. Stanyon R, Studer M, Dragone A, De Benedictis G, Brancati C (1988) Population cytogenetics of Albanians in Cosenza (Italy): frequency of Qand C-band variants. International Journal of Anthropology 3: 19-29.

11. Kalz L, Kalz-Fuller B, Hedge S, Schwanitz G (2005) Polymorphism of Qband heterochromatin; qualitative and quantitative analyses of features in 3 ethnic groups (Europeans, Indians, and Turks). Int J Hum Genet 5: 153-163.

12. Décsey K, Bellovits O, Bujdoso GM (2006) Human chromosomal polymorphism in Hungarian sample. Int J Hum Genet 6: 177-183.

13. Ibraimov AI, Mirrakhimov MM (1982a) Human chromosomal polymorphism. III. Chromosomal Q-polymorphism in Mongoloids of northern Asia. Hum Genet 62: 252-257.

14. Ibraimov AI, Mirrakhimov MM (1982b) Human chromosomal polymorphism. IV. Chromosomal Q-polymorphism in Russians living in Kirghizia. Hum Genet 62: 258-260.

15. Ibraimov AI, Mirrakhimov MM (1982c) Human chromosomal polymorphism. V. Chromosomal Q-polymorphism in African populations. Hum Genet 62: 261-265.

16. Ibraimov AI, Mirrakhimov MM, Nazarenko SA, Axenrod EI, Akbanova GA (1982) Human chromosomal polymorphism. I. Chromosomal Qpolymorphism in Mongoloid populations of Central Asia. Hum Genet 60: $1-7$. 
Citation: Ibraimov Al (2016) Chromosomal Q-heterochromatin Regions in Alcoholics and Drug Addicts. Biol Med (Aligarh) 8: 346. doi: $10.4172 / 0974-8369.1000346$

Page 5 of 5

17. Ibraimov AI, Mirrakhimov MM, Axenrod EI, Kurmanova GU (1986) Human chromosomal polymorphism. IX. Further data on the possible selective value of chromosomal Q-heterochromatin material. Hum Genet 73: 151-156.

18. Ibraimov AI, Kurmanova GU, Ginsburg EK, Aksenovich TI, Axenrod EI (1990) Chromosomal Q-heterochromatin regions in native highlanders of Pamir and Tien-Shan and in newcomers. Cytobios 63: 71-82.

19. Ibraimov AI, Axenrod EI, Kurmanova GU, Turapov DA (1991) Chromosomal Q-heterochromatin regions in the indigenous population of the northern part of West Siberia and new migrants. Cytobios 67: 95-100.

20. Ibraimov AI, Karagulova GO, Kim EY (1997) Chromosomal Qheterochromatin regions in indigenous populations of the Northern India. Ind J Hum Genet 3: 77-81.

21. Ibraimov AI, Akanov AA, Meymanaliev TS, Karakushukova AS, Kudrina NO, et al. (2013) Chromosomal Q-heterochromatin polymorphisms in 3 ethnic groups (Kazakhs, Russians and Uygurs) of Kazakhstan. Int J Genet 5: 121-124.

22. Erikson CK (1979) Factors affecting the distribution and measurement of ethanol in the body. In: Majchrowicz E, Noble EP (eds). Biochemistry and pharmacology of ethanol. Plenum Press, London, pp. 9-23.

23. Moor R (1964) Alcoholism in Japan. Quart J Stud Alcohol 25: 142-150.

24. Keller M (1970) The great Jewish mystery. British J Addict 64: 287-296.

25. Autkiewicz HL (1987) Chinese alcohol use and Hong Kong. Alcoholism 23: 3-18.

26. Miroshnichenko LD, Pelipas VE (1991) Regionalnii razlichia v rasprostranennosti alcoholisma v USSR. Voprosy narcologii 3: 29-32. (in Russian).
27. Ibraimov AI (1983) Chromosome preparations of human whole lymphocytes - an improved technique. Clin Genet 24: 240-242.

28. Hungerford DA (1965) Leucocytes cultured from small inocula of whole blood and the preparation of metaphase chromosomes by treatment with hypotonic KCl. Stain Technology 40: 333-338.

29. Ibraimov AI (1993) The origin of modern humans: a cytogenetic model Hum Evol 8: 81-91.

30. Ibraimov AI (2003) Condensed chromatin and cell thermoregulation. Complexus 1: 164-170.

31. Ibraimov AI (2004-2005) The origin of condensed chromatin, cell thermoregulation and multicellularity. Complexus 2: 23-34.

32. Ibraimov AI, Akanov AA, Meimanaliev TS, Sharipov KO, Smailova RD, et al. (2014) Human Chromosomal Q-heterochromatin Polymorphism and Its Relation to Body Heat Conductivity. Int J Genet 6: 142-148.

33. Pelipas VE, Miroshnichenko LD (1991) Dinamika zabolevaemosti alcoholismom v USSR za 25 let i otsenka slogivsheysya situatsii. Voprosy narcologii 1: 31-34. (in Russian).

34. Dahlgren L (1978) Female alcoholic. Acta Psychiat Scand 57: 325-335.

35. Goodwin DW (1988) Is alcoholism hereditary? Second Edition. Ballantine Books, New York, pp. 1-261.

36. Ibraimov AI, Karagulova GO, Kim EY (2000) The relationship between the Y chromosome size and the amount of autosomal Q-heterochromatin in humanpopulations. Cytobios 102: 35-53. 